\title{
Private health insurance coverage-related lawsuits
}

\author{
Ações judiciais relacionadas às coberturas assistenciais na saúde suplementar \\ Acciones judiciales relacionadas con la cobertura de prestaciones en la salud complementaria
}

\author{
Ana Beatriz Perez Afonso' \\ ORCID: 0000-0002-7958-4111 \\ Mayra Gonçalves Menegueti' \\ ORCID: 0000-0001-7955-4484 \\ Thamiris Ricci de Araújo' \\ ORCID: 0000-0003-4571-9855 \\ Lucieli Dias Pedreschi Chaves' \\ ORCID: 0000-0002-8730-2815 \\ Ana Maria Laus' \\ ORCID: 0000-0002-6339-0224
}

'Universidade de São Paulo. Ribeirão Preto, São Paulo, Brazil.

How to cite this article:

Afonso ABP, Menegueti MG, Araújo TR, Chaves LDP, Laus AM. Private health insurance coverage-related lawsuits. Rev Bras Enferm. 2020;73(3):e20180748. doi: http://dx.doi.org/10.1590/0034-7167-2018-0748

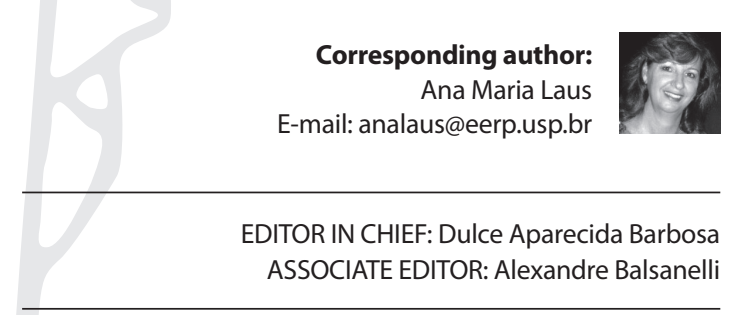

Submission: 09-21-2018

Approval: 04-30-2019

\begin{abstract}
Objectives: to analyze lawsuits brought by beneficiaries of health insurance operators. Methods: this was a cross-sectional descriptive study carried out in a large-capacity private health insurance operator using data collected by the company from 2012 to 2015. Results: ninety-six lawsuits were brought by 86 beneficiaries regarding medical procedures (38.5\%), treatments $(26.1 \%)$, examinations (14.6\%), medications $(9.4 \%)$, home care $(6.2 \%)$, and other types of hospitalization (5.2\%). The procedures with the highest number of lawsuits were percutaneous rhizotomy; chemotherapy; treatment-related positron-emission tomography scans; and for medications relative to antineoplastic and Hepatitis $\mathrm{C}$ treatment. Conclusions: the lawsuits were filed because of the operators' refusal to comply with items not established in contracts or not regulated and authorized by the Brazilian National Regulatory Agency for Private Health Insurance and Plans, refusals considered unfounded.
\end{abstract}

Descriptors: Judicial Decisions; Right to Health; Supplemental Health; Health's Judicialization; Health.

\section{RESUMO}

Objetivos: analisar as ações judiciais demandadas por beneficiários de uma operadora de plano de saúde. Métodos: estudo descritivo de corte transversal desenvolvido em uma operadora de plano privado de saúde de grande porte, utilizando dados compilados pela empresa no período de 2012 a 2015. Resultados: foram movidas 96 ações judiciais por 86 beneficiários, referentes a procedimentos médicos $(38,5 \%)$, tratamentos $(26,1 \%)$, exames $(14,6 \%)$, medicamentos $(9,4 \%)$, Home Care $(6,2 \%)$ e $5,2 \%$ a outros tipos de internações. O maior número de ações dentre os procedimentos foi rizotomia percutânea; para tratamentos, a quimioterapia; exames solicitados de tomografia por emissão de pósitrons; para medicamentos, os antineoplásicos e para tratamento de Hepatite C. Conclusões: a razão para as demandas judiciais impetradas foi a negativa da operadora em atender os itens não pertencentes ao escopo do que foi contratado pelo beneficiário ou itens não regulamentados e autorizados pela Agência Nacional de Saúde Suplementar, portanto sendo consideradas improcedentes.

Descritores: Decisões Judiciais; Direito à Saúde; Saúde Suplementar; Judicialização da Saúde; Saúde.

\section{RESUMEN}

Objetivos: analizar las acciones judiciales iniciadas por beneficiarios de planes de salud de prepago. Métodos: estudio descriptivo, transversal, desarrollado en importante operadora de planes de salud de prepago, utilizando datos recopilados por la empresa entre 2015 y 2015. Resultados: fueron impulsadas 96 acciones judiciales por parte de 86 beneficiarios, referentes a procedimientos médicos $(38,5 \%)$, tratamientos $(26,1 \%)$, estudios $(14,6 \%)$, medicación $(9,4 \%)$, Home Care $(6,2 \%)$ y 5,2\% por otros tipos de internación. La mayoría de acciones por procedimientos correspondió a rizotomía percutánea; en tratamientos, a quimioterapia; en estudios, a tomografía por emisión de positrones; en medicamentos, a antineoplásicos y para tratar la hepatitis C. Conclusiones: motivaron las acciones judiciales interpuestas la negativa de la operadora de planes de salud a cubrir prestaciones no incluidas en el alcance del plan contratado por el beneficiario, así como asuntos no reglados y autorizados por la Agencia Nacional de Salud Complementaria, considerándose, en consecuencia, improcedentes. Descriptores: Decisiones Judiciales; Derecho a la Salud; Salud Complementaria; Judicialización de la Salud; Salud. 


\section{INTRODUCTION}

The relationship between law and health care is a great challenge for the future of healthcare systems in Brazil and worldwide. Considering that the healthcare sector requires ongoing regulation to deal with market flaws, the Judiciary becomes, par excellence, the field for solving conflicts between needs, imposed rights, and public and private healthcare institutions ${ }^{(1)}$.

Based on a context of scarce resources, increased life expectancy, and spread of diseases, it is a challenge for public powers to effectively implement the right to health, thus encouraging lawsuits that compel governments to supply health-related goods and services ${ }^{(2)}$.

Both supplemental health and public system face problems, and lawsuits brought by beneficiaries of health insurance plans demanding coverage, decreased waiting periods, unilateral terminations, and unlimited hospitalizations are frequent, impacting the Judiciary ${ }^{(3-4)}$.

Health judicialization generates tension among different interests and represents a possibility for claims from citizens and institutions to ensure rights established by national and international legislation ${ }^{(5)}$. The Judiciary is the path to establish the right to health relative to individual demands for hospital medications, devices, and supplies. The expression "health's judicialization" generally refers to the phenomenon in which political and social decisions regarding health care are transferred from the Legislative and Executive branches to the Judiciary ${ }^{(6)}$.

The aim of studies about lawsuits involving coverage restrictions is to present elements to improve the regulations and practices of a sector that has a great impact on the funding and operation of the Brazilian healthcare system ${ }^{(7)}$.

One immediate consequence of such lawsuits is the use of unexpected economic resources that have to be quickly allocated to comply with court orders specifically issued for this purpose ${ }^{(8)}$.

The judicialization of health is a multi-faceted phenomenon that involves political, social, ethical, and sanitary aspects that go far beyond its legal component and the management of public services. If on one hand, a large portion of the budget is allocated to meet specific needs of a few patients, on the other hand, it may represent the only solution to improve, prolong, or save lives. However, judicial orders are not always based on clinical healthcare protocols or evidence that ensures efficiency and cost-benefit ratio. Assessment and control of the use of new technologies are a key aspect to establish whether to authorize the inclusion of new procedures, therapies, examinations, technologies, and medications ${ }^{(1)}$.

The literature on the topic is often directed toward the analysis of the problem in the Brazilian Unified Health System, with emphasis on the supply of medications. However, there is a lack of knowledge production about lawsuits and health insurance plans $^{(3,9)}$.

Studies that analyze the volume and objects of requests, as well as their economic burden can contribute to knowledge about and assessment of the impact of this phenomenon on the private healthcare sector. This scenario served as the basis of the present study, justified by the lack of information on the theme, given the current judicialization of health care.

\section{OBJECTIVES}

To analyze lawsuits brought by beneficiaries of health insurance operators.

\section{METHODS}

\section{Ethical aspects}

The present study was approved by the Research Ethics Committee of the College of Nursing of Ribeirão Preto at the University of São Paulo and the investigated health insurance operator, meeting the ethical requirements set forth by resolution 466/2012, under Certificate of Presentation for Ethical Appraisal (CAAE) protocol no. 46577015.6.0000.5393.

\section{Study design, setting, and period}

This was a quantitative cross-sectional study carried out in a health insurance operator that belongs to a cooperative system considered the world's largest medical work cooperative system and the largest medical healthcare network in Brazil, present in $84 \%$ of the national territory. The system is currently made up of 346 medical cooperatives that provide care to more than 18 million beneficiaries nationwide. It also owns $37 \%$ of the national health insurance market, with 120 thousand beneficiaries, an accredited network of 17 hospitals and specialized clinics, its own hospital, and 926 physicians.

\section{Sample, inclusion and exclusion criteria}

The present study analyzed 158 lawsuits filed against the health insurance operator from June 2012 to June 2015. Of these, 62 preliminary injunctions of beneficiaries from other operators for compliance by the investigated operator, maintenance of health insurance plans, adjustments, medical evidence, name withdrawal from Serasa (Brazilian credit research company), and exemption from waiting periods, were excluded. The inclusion criterion referred to lawsuits brought by beneficiaries of the investigated operator regarding healthcare coverage.

\section{Data collection}

Data collection was carried out using an instrument prepared specifically for the study, containing information about the patient's characteristics (age, gender, city of residence, marital status, type of insurance plan, active beneficiary or not), type of request (hospitalizations, medications, specific medical procedures, medical hospital materials, orthoses, prostheses, and treatments without coverage by the minimum mandatory coverage list of procedures stipulated by the Brazilian National Regulatory Agency for Private Health Insurance and Plans [ANS]), and the outcome of these preliminary injunctions. The data were obtained from the digitized document filing system kept by the company's legal department.

\section{Analysis of the results and statistics}

Quantitative analysis of the data was run using the Epi-info 6 program. 


\section{RESULTS}

Ninety-six health insurance coverage-related lawsuits were identified, of which $40 \%(n=38)$ were relative to business plans, followed by individual/family plans with $31 \%(n=30)$, and collective plans with $29 \%(n=28)$. In the three years investigated, 27 lawsuits were filed in the first year, 35 in the second year, and 34 in the third year.

Of the beneficiaries $(n=86)$ who brought the lawsuits, $50 \%(n=43)$ were women, $45.2 \%(n=39)$ were aged between 51 and 80 years, $56.8 \%(n=49)$ were single, and $58.9 \%(n=51)$ resided in the region where the health insurance operator was located. Moreover, $9 \%(n=8)$ of the beneficiaries brought more than one lawsuit, and two preliminary injunctions mentioned two beneficiaries.

The objects of the lawsuits were grouped by similarity and are presented in Figure 1. The alleged reason for refusing to comply with the lawsuits was that the objects were not included in the minimum mandatory coverage list of procedures established by the ANS.

The most frequent items in each group were specified to help understand the analysis carried out in each one of them.

Of the 96 lawsuits, the most prevalent category was medical procedures, with $38.5 \%(n=37)$. Figure 2 presents the number of lawsuits filed according to medical procedure. Of these 37 procedures that composed this group, $27 \%(n=10)$ referred to percutaneous rhizotomy. Although this procedure is included in the ANS list, its guidelines are regulated according to assessment criteria, made available only to patients with lumbar facet syndrome.

Of the 96 lawsuits, $26.1 \%(n=25)$ referred to treatment refusals, and chemotherapy was the most common, with $44 \%(n=11)$, as presented in Table 1. The reasons for refusals of preliminary injunctions mostly referred to treatments in non-accredited services, with 55\% $(n=6)$. Other reasons corresponded to procedures not covered by the ANS list, with $18 \%(n=2)$, non-regulated plans, with $9 \%(n=1)$, defaulting beneficiaries, with $9 \%(n=1)$, and beneficiaries in waiting period, with $9 \%(n=1)$.

Of the total number of lawsuits, $14.6 \%(n=14)$ referred to tests, as shown in Table 2. Positron-emission tomography stood out Paulo, 2015

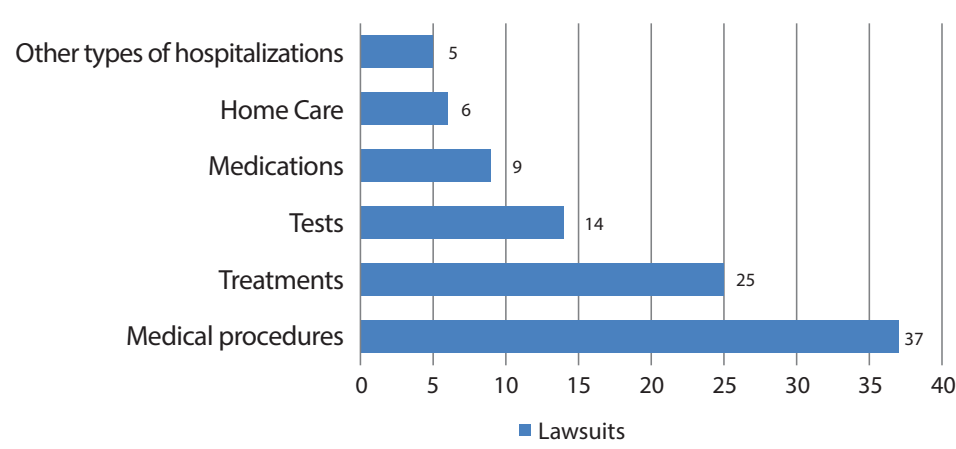

Figure 1 - Distribution of lawsuits $(n=96)$ regarding health care coverage according to reason, Ribeirão Preto, São Paulo, 2015

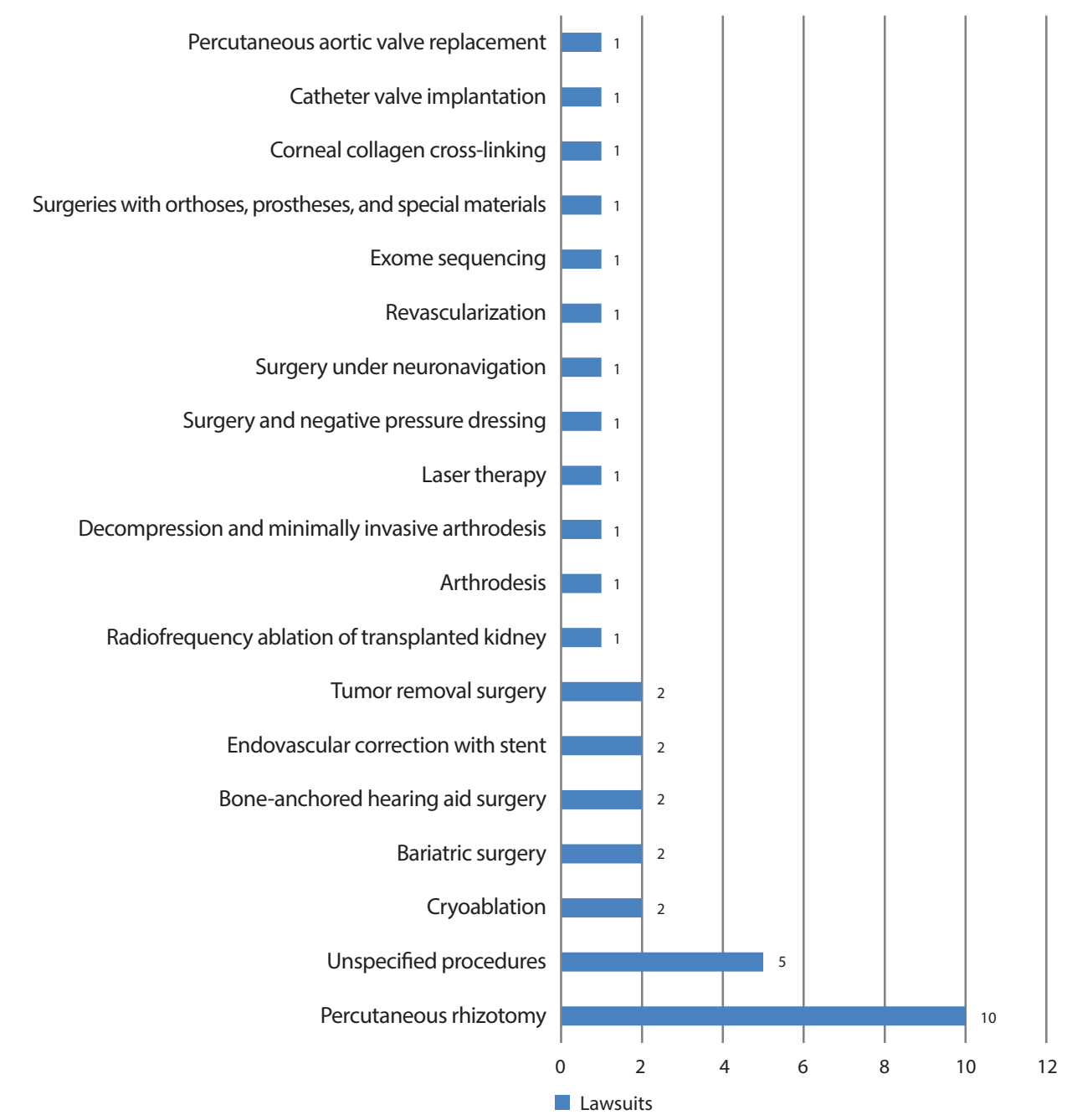

Figure 2 - Number of lawsuits filed according to medical procedure requested, Ribeirão Preto, São

with $50 \%(n=7)$, whose reason for refusal was the non-coverage of the procedure in the ANS list at the time of the request.

Medication supply corresponded to $9.4 \%(n=9)$ of the total number of lawsuits. Most requests were of antineoplastic drugs, with $56 \%(n=5)$, and medications for hepatitis $C$ treatment, with $44 \%(n=4)$. The reason for refusal for antineoplastic drugs was the 
absence of its registry in the Brazilian National Health Surveillance Agency (ANVISA, as per its acronym in Portuguese) at the time of the preliminary injunctions.

Table 1 - Number of lawsuits filed according to treatment requested, Ribeirão Preto, São Paulo, 2015

\begin{tabular}{lcc}
\hline TREATMENTS REQUESTED & N & $\%$ \\
\hline Chemotherapy & 11 & 44 \\
Intensity-modulated radiation therapy (IMRT) & 7 & 28 \\
Intravitreal corneal injection & 3 & 12 \\
TheraSuit physical therapy method & 1 & 04 \\
Chemotherapy and radiation therapy & 1 & 04 \\
Psychological treatment & 1 & 04 \\
Conformal radiation therapy & 1 & 04 \\
Total & 25 & $100 \%$ \\
\hline
\end{tabular}

Table 2 - Number of lawsuits filed according to treatment requested, Ribeirão Preto, São Paulo, 2015

\begin{tabular}{lcc}
\hline EXAMINATIONS REQUESTED & N & $\%$ \\
\hline Positron-emission tomography & 07 & 50 \\
Optical coherence tomography (OCT) & 02 & 15 \\
Radiofrequency ablation of celiac plexus & 01 & 07 \\
Factor V Leiden and prothrombin gene mutation & 01 & 07 \\
Liver ultrasound hormone dosage & 01 & 07 \\
Neuraxis magnetic resonance image & 01 & 07 \\
Unspecified test & 01 & 07 \\
Total & 14 & $100 \%$ \\
\hline
\end{tabular}

Home care services represented $6.2 \%(n=6)$ of the total number of lawsuits, and the requests contested 12/24 hours nursing care and specific care, such as physical therapy, speech therapy, equipment, and supplies. In these cases, the health insurance operator alleged that this type of service was not provided for in the contracts.

Last, in lawsuits filed for other types of hospital admissions, such as psychiatric and intensive care units, corresponded to $5.2 \%(n=5)$, and were refused on the grounds of the institution belonging to a "non-accredited network".

\section{DISCUSSION}

There is an increasing demand of healthcare-related lawsuits, both in the public and private sector. Effectiveness of health care is sought through its judicialization, by means of court orders that sentence service providers to assist users in what is understood as correct ${ }^{(10)}$.

The number of lawsuits in the three years analyzed presented a linear trend. Currently, there are no scientific data in the country regarding the number of lawsuits brought by beneficiaries, especially those in the private healthcare sector. A study carried out in a high-management entity that catalogued all lawsuits according to Brazilian state, regardless of its object, found 3.569 health insurance coverage-related lawsuits for a population of 681,000 beneficiaries $^{(11)}$.

Since the establishment of the ANS in 2000, its list has undergone regular reviews to ensure the inclusion of new medical procedures and technologies due to the evolution of medicine and care practices ${ }^{(12)}$.
The direct cost of the use of new technologies and savings due to prevented procedures must be considered, in spite of the lack of tools that allow for a prospective assessment of the impact of this incorporation ${ }^{(13)}$.

In this scenario, it is necessary to discuss the financial figures regarding lawsuits to enable the analyses of this financial balance in operating revenues and their inclusion in annual budgets. In the health judicialization context, it is important to identify this demand and the reasons given by service providers to refuse coverage, in order to better understand these reasons. Implementing budgetary projections based on the profile of these beneficiaries could improve the performance of indicators, as well as the restructuring of health insurance coverage.

In the private healthcare sector, by recommendation of the ANS, health insurance coverage is established by contract. However, this conflicts with the Judiciary's understanding that health insurance operators must comply with what the beneficiaries and the Judiciary understand as correct and then can seek preliminary injunction reversal only after approving the procedures to avoid paying fines ${ }^{(14)}$.

This phenomenon has been called interlocutory relief, in which the only court criterion for the conceding preliminary injunctions is the confirmation of beneficiaries' need for urgent access to procedures ${ }^{(9)}$.

Court sentences require both maximum urgency and careful assessment. These decisions are at the charge of those who have the duty to decide; however, they do not necessarily have specific knowledge on the theme.

International studies also show controversial court sentences for new interventions made under uncertainty, which may not only cause harm to patients, but prove ineffective, possibly incurring unnecessary increase in care costs. It is essential to introduce assessment systems of new technologies to provide information to those responsible for decision making. Basic discussions about evidence-based medicine and its assumptions are also necessary. Therefore, establishing technically correct methods and developing preemptive care guidelines can be some of the few sustainable strategies available to health insurance operators to question unbridled and not always critical demands ${ }^{(15)}$.

In Brazil, an original and growing initiative has emerged to overcome the consequences of court interpretations, which establishes technical assistance center for health-related lawsuits (NAT, as per its acronym in Portuguese). Because the topic requires technical and specific knowledge for decision making, these centers provide the Judiciary with assistance to address the population's demands. These centers provide multidisciplinary professionals such as physicians, pharmacists, nurses, nutritionists, and managers, enabling technical support to better analyze lawsuit requests ${ }^{(12)}$.

The present study, showed that the most prevalent requests present in lawsuits referred to medical procedures, with $38.5 \%$ $(n=37)$, corroborating a study carried out in a self-management entity, where this was also the main request $(31.4 \%)^{(9)}$.

However, studies about the judicialization of health care in the public sector, especially in the Brazilian Unified Health System (SUS, as per its acronym in Portuguese), show that the most prevalent demand is for medications, representing $29.6 \%$ of the requests ${ }^{(14)}$. The findings of this study showed that in the health insurance operator (part of the private system), medications 
represented $9.4 \%$ of the lawsuits, or the fourth most common reason indicated by beneficiaries.

A systematic review of the international literature about the use of judicial procedures to provide medication showed that these are the most significant object of lawsuits, a reality specifically characteristic of Brazil( ${ }^{(16)}$.

Studies carried out in the states of São Paulo, Santa Catarina, and Minas Gerais identified that most of the lawsuits filed against the SUS presented medical prescriptions from private healthcare services, showing that these lawsuits had been filed by the higherincome population ${ }^{(17)}$.

Additionally, it is worth mentioning the great heterogeneity of healthcare service users, who present different needs according to their social, demographic, economic, and epidemiological characteristics. This affects the demand for healthcare services in different geographic regions. As a consequence, the mapping of lawsuits can become a healthcare organization process ${ }^{(5)}$.

Regarding types of treatment, chemotherapy was the most requested (44\%). This group included the preliminary injunctions whose reasons presented by the beneficiaries mostly referred to the option of undertaking treatment in a non-accredited service in the city of São Paulo. Moreover, this group also included beneficiaries with plans that did not include this type of treatment, but who had to request it because they needed it.

It is important to reflect on the desire of beneficiaries to receive care in specialized services recognized as reference centers for the treatment of their illnesses. In this case, health judicialization has become a means of access, pointing to quite different individual needs ${ }^{(18)}$.

In terms of tests, although positron-emission tomography is no longer a new technology and several studies have been carried out to justify or increase its use in different areas and disorders, the ANS has a restricted set of indications which must be considered. In these decisions, the inclusion of health technologies prevails, because reference studies require time and consistent methodology and are at a slower rate than their actual use by the medical community, thus generating conflicts ${ }^{(11)}$.

Home care in the private health sector is neither part of the minimum mandatory coverage list of procedures nor regulated by the ANS; however, health insurance operators can choose to provide this service, establishing their own inclusion criteria for users of healthcare programs, being offered as a "benefit"(5). Health insurance operators that choose to provide this healthcare modality are only subject to regulation by ANVISA, by means of the Resolution of the Collegiate Board of Directors (RDC)(19), which specifies organizational aspects of home care, although it does not establish contracting criteria or regulation mechanisms.

Refusal of treatment by health insurance plans has become common, supported by arguments of non-inclusion by the minimum mandatory coverage list of procedures required by the ANS, such as home care, which is financed by health insurance operators ${ }^{(9)}$.

Regarding other types of hospitalization, lawsuits brought by health insurance beneficiaries contesting coverage, reduction in waiting periods, unilateral terminations, and unlimited hospitalizations. This is an example of a dispute involving the right to access, limitations set by healthcare regulations, and the absence of clear criteria for technology incorporation ${ }^{(3)}$.
The findings of this study identified that the care provision refusals of the health insurance operator that led to lawsuits were based on the absence of contractual coverage, because the object was not present in the minimum mandatory coverage list of procedures of the ANS: request of non-accredited services; medications without appropriate regulation by the ANVISA; and services not provided for in established contracts.

The provision of healthcare services by health insurance operators involves very clear contractual relationships, rights, and duties from both parts.

Since its establishment, the ANS has regulated the healthcare sector in its various fields of practice, such as by defining coverage rules of a reference healthcare plan, establishing a minimum mandatory coverage list of procedures, and defining operating parameters for health insurance operators and the accredited network ${ }^{(12)}$.

Health insurance plans are faced with the challenge of providing the minimum mandatory coverage list of procedures to their beneficiaries. They must also regulate the incorporation of new treatments that emerge at a quick pace, resulting in considerable economic impact on operators ${ }^{(9)}$.

The list of procedures is updated every two years to include and exclude items, thus allowing the adoption of new technologies. However, these updates are not always based on feasibility studies to assess the increased costs incurred by these new technologies $^{(12)}$.

\section{Study limitations}

This study was carried out with a single health insurance operator, which does not allow for generalizations to other contexts. Also, the financial impact of refusals on the health insurance operator could not be verified.

\section{Contributions to the nursing, healthcare, or public policy areas}

The judicialization of health care is a recurrent theme in the public sphere and has been included in many discussions, although with little mention to the private segment.

However, in many situations, the Judiciary has been criticized for interfering with the healthcare area, disregarding established norms and management policies, and enforcing laws based on the right to life. Even though health is priceless, it is an important asset that comes with a cost.

The financial burden of the judicialization of health care, both in the public and private healthcare system, should alert managers to create specific areas to analyze and follow up on these lawsuits, considering that, in the present study, the same beneficiaries resorted to the Judiciary more than once. Financial expenses with preliminary injunctions are not fixed costs that health insurance operators are able to measure. Thus, it is of utmost importance that operators manage expenses and reserves for these purposes.

The private health segment is subject to great conflict because it requires supervision from the ANS, which in turn has been improving the follow-up and assessment system of the care provided by health insurance operators to their beneficiaries. 
In this respect, assessment processes are highly valuable to the operation of systems, and audits are systematic assessments in which nurses can participate as part of the team, representing an important job opportunity. There has been a significant increase in the number of nurses working for healthcare operators in the insurance-health segment and medical-hospital healthcare plans.

The audit areas of healthcare institutions, both public and private, must address the judicialization of health care on a daily basis. Audits, lawsuit management, current legislation, ANS regulations, and knowledge about hospital billing practices are factors that permeate the basis of lawsuits, and, therefore, must be included in the work knowledge of nurses in this specific area.

It is necessary to learn about the reasons behind the lawsuits brought by beneficiaries; however, auditors must be technically and legally prepared, evaluating requests based on evidencebased practices.
The issue of health judicialization is far from reaching a shortterm resolution, and discussions about the financial effects of this process must be considered.

In this respect, there is a prevalence of investigations about the public healthcare system. This shows the importance of the present study, which analyzes the private system and allows for a broader discussion about the effects of health judicialization on the reality of the health insurance operator investigated, including its limits and responsibilities.

\section{CONCLUSIONS}

The analysis of the lawsuits brought by beneficiaries of the investigated health insurance operator showed that the requests were not provided for in contracts or not part of the items regulated and authorized by the ANS, thus considered unfounded.

\section{REFERENCES}

1. Medici AC. Judicialização, integridade e financiamento da saúde. Diagn Tratamento [Internet]. 2010 [cited 2018 Aug 16];15(2):81-7. Available from: http://files.bvs.br/upload/S/1413-9979/2010/v15n2/a81-87.pdf.

2. Verbicaro LP, Santos ACV. The necessity of parameters for effectuation of right to health: judicial action for access to growth hormone in the State of Pará. Rev Direito Sanit. 2017;17(3):185-211. doi: 10.11606/issn.2316-9044.v17i3p185-211

3. Alves DC, Bahia L, Barroso AF. O papel da Justiça nos planos e seguros de saúde no Brasil. Cad Saúde Pública [Internet]. 2009 [cited 2018 Aug 16];25(2):279-90. Available from: http://www.scielo.br/pdf/csp/v25n2/06.pdf

4. Silva Jr GB, Dias ER. Evaluation of patient's satisfaction in a public-private health facility in Northeastern Brazil and the judicialization of healthcare. Rev Direito Sanit. 2016;17(2):13-29. doi: 10.11606/issn.2316-9044.v17i2p13-29

5. Silva KL, Sena RR, Feuerwerker LCM, Souza CG, Silva PM, Rodrigues AT. The right to health: challenges revealed by the home care provision in supplementary health services. Saúde Soc. [Internet]. 2013 [cited 2018 Aug 18];22(3):773-84. Available from: http://www.scielo.br/pdf/sausoc/ v22n3/en_11.pdf.

6. Guazzelli AS. A busca da justiça distributiva no Judiciário por meio das relações contratuais: uma análise a partir dos planos de saúde. [dissertation]. São Paulo: Faculdade de Direito, Universidade de São Paulo, 2013.

7. Scheffer M. Coberturas assistenciais negadas pelos planos e seguros de saúde em ações julgadas pelo tribunal de justiça do Estado de São Paulo. Rev Direito Sanit [Internet]. 2013 [cited 2018 Aug 18];14(1):122-32. Available from: http://www.revistas.usp.br/rdisan/article/view/56627/59644.

8. Carlini AL. A judicialização da saúde no Brasil e a participação política na construção de orçamentos. In: Conselho Nacional de Pesquisa e Pós-Graduação em Direito. Anais. XIX Encontro Nacional do Copendi. Fortaleza - CE, p. 7052-69[Internet]. 2010[cited 2018 Aug 18]. Available from: http://www.publicadireito.com.br/conpedi/manaus/arquivos/anais/fortaleza/3201.pdf.

9. Oliveira JAD, Fortes PAC. De que reclamam, afinal? estudo das ações judiciais contra uma operadora de plano de saúde. Rev Direito Sanit. 2013; 13(3):33-58. doi: 10.11606/issn.2316-9044.v13i3p33-58

10. Arruda SC. Análise sobre a judicialização da saúde no estado de Mato Grosso no período de 2011-2012. Cad Ibero Am Direito Sanit [Internet]. 2017 [cited 2018 Aug 18];6(1). Available from: https://www.cadernos.prodisa.fiocruz.br/index.php/cadernos/article/view/308/438

11. Oliveira JAD, Fortes PAC. Demandas jurídicas por coberturas assistenciais: estudo de caso: CASSI. [dissertation]. São Paulo: Faculdade de Saúde Pública, Universidade de São Paulo, 2010.

12. Agência Nacional de Saúde Suplementar. Caderno de Informação da Saúde Suplementar: beneficiários, operadoras e planos. ANVISA [Internet] 2013 [cited 2018 Aug 18] Rio de Janeiro (RJ) Available from: http://www.ans.gov.br/images/stories/Materiais_para_pesquisa/ Perfil_setor/Caderno_informacao_saude_suplementar/2013_mes06_caderno_informacao.pdf.

13. Ceschin M. O impacto do novo rol de procedimentos da ANS nos custos das operadoras de planos de saúde. Deb GV Saúde [Internet]. 2011 [cited 2018 Aug 18); (11) Available from: http://bibliotecadigital.fgv.br/ojs/index.php/debatesgvsaude/article/viewFile/23146/21912.

14. Rodríguez AMMM. O processo da judicialização da saúde como via de acesso à atenção integral: o retrato de um município de grande porte do estado de São Paulo. [dissertation]. Ribeirão Preto-SP: Escola de Enfermagem de Ribeirão Preto, Universidade de São Paulo, 2014.

15. Olberg B, Fuchs S, Matthias K, Nolting A, Perleth M, Busse R. Evidence-based decision-making for diagnostic and therapeutic methods: the changing landscape of assessment approaches in Germany. Health Res Policy Syst [Internet]. 2017 [cited 2018 Aug 18);15:89. doi: 10.1186/ s12961-017-0253-1.

16. Leitão LCA, Simões MOS, Simões AEO, Alves BC, Barbosa IC, Pinto MEB. Judicialização da saúde na garantia do acesso ao medicamento. 
Rev Cienc Salud (Bogotá) [Internet]. 2014 [cited 2018 Aug 18];16(3):360-70. Available from: https://www.scielosp.org/article/rsap/2014. v16n3/361-370/

17. Cabral U, Rezende LF. Análise das ações judiciais individuais para fornecimento de medicamentos em São João da Boa Vista. Rev Direito Sanit. 2015;16(1):59-77. doi: https://doi.org/10.11606/issn.2316-9044.v16i1 p59-77.

18. Gomes FFC, Cherchiglia ML, Machado CD, Santos VC, Acurcio FA, Andrade EIG. Acesso aos procedimentos de média e alta complexidade no Sistema Único de Saúde: uma questão de judicialização. Cad. Saúde Pública [Internet]. 2014 [cited 2018 Aug 18];30(1):31-43. Available from: http://www.scielo.br/pdf/csp/v30n1/0102-311X-csp-30-01-00031.pdf

19. Ministério da Saúde (BR). Agência Nacional de Vigilância Sanitária. Resolução n. 11, de 26 de janeiro de 2006. Dispõe sobre o regulamento técnico de funcionamento de serviços que prestam atenção domiciliar. Diário Oficial [da] República Federativa do Brasil, Brasília, DF, 30 jan. 2006. Seção 1, p. 1-2. Suplemento. 